Article

\title{
Biochemical Properties of Polyphenol Oxidases from Ready-to-Eat Lentil (Lens culinaris Medik.) Sprouts and Factors Affecting Their Activities: A Search for Potent Tools Limiting Enzymatic Browning
}

\author{
Małgorzata Sikora, Michał Świeca* ${ }^{\mathbb{D}}$, Monika Franczyk ${ }^{\circledR}$, Anna Jakubczyk $\mathbb{B}^{\text {, }}$

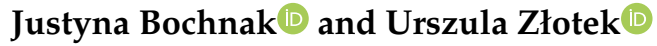 \\ Department of Biochemistry and Food Chemistry, University of Life Sciences, Skromna Str. 8, \\ 20-704 Lublin, Poland; malgorzata.sikora@up.lublin.pl (M.S.); monika.franczyk@up.lublin.pl (M.F.); \\ anna.jakubczyk@up.lublin.pl (A.J.); just.bochnak@gmail.com (J.B.); urszula.zlotek@up.lublin.pl (U.Z.) \\ * Correspondence: michal.swieca@up.lublin.pl; Tel.: +48-81-4623327; Fax: +48-81-4623324
}

Received: 12 March 2019; Accepted: 6 May 2019; Published: 7 May 2019

\begin{abstract}
Enzymatic browning of sprouts during storage is a serious problem negatively influencing their consumer quality. Identifying and understanding the mechanism of inhibition of polyphenol oxidases (PPOs) in lentil sprouts may offer inexpensive alternatives to prevent browning. This study focused on the biochemical characteristics of PPOs from stored lentil sprouts, providing data that may be directly implemented in improving the consumer quality of sprouts. The purification resulted in approximately 25-fold enrichment of two PPO isoenzymes (PPO I and PPO II). The optimum $\mathrm{pH}$ for total PPOs, as well as for PPO I and PPO II isoenzymes, was 4.5-5.5, 4.5-5.0, and 5.5, respectively. The optimal temperature for PPOs was $35^{\circ} \mathrm{C}$. Total PPOs and the PPO I and PPO II isoenzymes had the greatest affinity for catechol $\left(K_{m}=1.32,1.76\right.$, and $0.94 \mathrm{mM}$, respectively). Ascorbic acid was the most effective in the inhibition of dark color formation by total PPOs, and showed ca. $62 \%, 43 \%$, and $24 \%$ inhibition at 20-, 2-, and 0.2-mM concentrations. Ascorbic acid, L-cysteine, and sodium metabisulfite $(20 \mathrm{mM})$ significantly inhibited color development in the reactions catalyzed by both isoenzymes of PPO. $\mathrm{Ba}^{2+}, \mathrm{Fe}^{3+}$, and $\mathrm{Mn}^{2+}(10 \mathrm{mM})$ completely inhibited PPO activity. This study of the effect of antibrowning compounds and cations on PPO activity provides data that can be used to protect lentil sprouts against enzymatic browning during storage and processing.
\end{abstract}

Keywords: biochemical characteristic; enzymatic browning; inhibitory profile; lentil; sprouts; polyphenol oxidase; purification

\section{Introduction}

Polyphenol oxidases (PPOs) (EC 1.14.18.1, EC 1.10.3.1, or EC 1.10.3.2) are widely distributed in the plant kingdom, and their level and activity are dependent on the age, species, variety, maturity, and stress status of plants [1,2]. In addition, they are located in certain organelles, such as chloroplast thylakoids, peroxisomes, and mitochondria [1]. According to substrate specificity, three main types of phenol oxidases are known: (I) Monophenol monooxygenase (also called tyrosinase, monophenol oxidase, or cresolase) catalyzes the hydroxylation of monophenol to ortho-diphenol and the oxidation of diphenol to ortho-quinone; (II) diphenol oxidase (also called catechol oxidase, polyphenol oxidase, or $o$-diphenolase) catalyzes the oxidation of ortho-phenol, but cannot catalyze the oxidation or monooxygenation of metaphenol and para-phenol; and (III) laccase catalyzes the oxidation of ortho-phenol and para-phenol, but cannot catalyze the oxidation of monophenol and metaphenol [3]. This classification, although commonly used, also has some inaccuracies, e.g., in the case of mung 
bean [4] or tobacco [5] laccases, which share many substrates with PPOs. Enzymatic browning of plant-derived foods (including sprouts) contributes to a decrease in the sensory properties and marketability of fruits and vegetables [6-9]. The formation of brown or black pigments is due to increased activity of PPOs, resulting in the polymerization of quinones [2,7]. Additionally, increased activity of PPOs can decrease the level of phenolic compounds, i.e., plant secondary metabolites with well-documented nutraceutical properties $[10,11]$. Due to these facts, the characterization of PPO activities or the removal of reactants such as oxygen and phenolic compounds, especially those concerning potential inhibitors, are of increasing interest in the food industry. As one of the antibrowning agents, ascorbic acid inactivates PPOs irreversibly in the absence of PPO substrates, probably through binding to its active site, preferentially in its oxy form. Additionally, it can reduce reaction products, limiting the formation of a dark color. Cysteine activity is usually attributed to various mechanisms, e.g., its nucleophilic reactivity toward quinones to give a colorless adduct or its ability to reduce $o$-quinones to their polyphenol precursors. Citric acid and ethylenediaminetetraacetic acid sodium salt (EDTA) chelate copper at an enzyme-active site [12,13].

Polyphenol oxidase has been widely studied in fruits, vegetables, and mushrooms, e.g., eggplant (Solanum melongena) [14], persimmon [15], broccoli (Brassica oleracea var. botrytis italica) [16], celery [17], and butter lettuce (Lactuca sativa var. capitata L.) [18]: However, there are very few data that have presented the characterization of PPOs from edible sprouts.

In this paper, we report the isolation, partial purification, and biochemical properties of two isoenzymes and total PPO activity in lentil sprouts (Lens culinaris Medik.). Special attention is placed on the factors affecting PPO activity, which may be useful for protecting sprouts against PPO-related undesirable changes in their quality.

\section{Materials and Methods}

\subsection{Chemicals}

Catechol, Diethylaminoethyl-Sepharose (DEAE-S), tris(hydroxymethyl)aminomethane (TRIS), ethylenediaminetetraacetic acid sodium salt (EDTA), 4-methylcatechol, gallic acid, caffeic acid, L-cysteine, ascorbic acid, and DL-dithiothreitol were obtained from Sigma-Aldrich (Poznań, Poland). All other chemicals were of analytical grade.

\subsection{Materials and Sprouting Conditions}

Seeds from the lentil cultivar Tina were purchased from PNOS S.A. Ozarów Mazowiecki (Poland). The seeds were sterilized in 10\% $(v / v)$ sodium hypochloride for $10 \mathrm{~min}$, drained, and washed with distilled water until they reached a neutral $\mathrm{pH}$. They were placed in distilled water and soaked for $6 \mathrm{~h}$ at $25^{\circ} \mathrm{C}$. The seeds were dark-germinated for 4 days in a growth chamber on Petri dishes (diameter, $125 \mathrm{~mm}$ ) lined with absorbent paper. Seedlings were watered daily with $5 \mathrm{~mL}$ of Milli-Q water [19].

\subsection{Enzyme Assay}

Polyphenol oxidase (PPO) activity was determined by measuring the initial rate of quinone formation, as indicated by an increase in the absorbance units (AUs) at $420 \mathrm{~nm}$. An increase in absorbance of $0.001 \mathrm{~min}^{-1}$ was taken as one unit of enzyme activity [20]. The increase in absorbance was linear with time for the first $120 \mathrm{~s}$. The sample contained $1 \mathrm{~mL}$ of a $0.05-\mathrm{M}$ substrate solution prepared in TRIS-HCl buffer $(50 \mathrm{mM}, \mathrm{pH} 6.5)$ and $0.05 \mathrm{~mL}$ of an enzyme solution. All measurements were performed in triplicate.

\subsection{Protein Determination}

Protein content was determined according to the dye-binding method proposed by Bradford [21] using bovine serum albumin as a standard. 


\subsection{Enzyme Extraction and Partial Purification}

One-hundred grams of sprouts were homogenized in $250 \mathrm{~mL}$ of $50 \mathrm{mM}$ TRIS-HCl buffer (pH 6.5) containing $10 \mathrm{mM}$ of ascorbic acid and $0.5 \%$ polyvinylpyrrolidone and were extracted with the aid of a magnetic stirrer for $1 \mathrm{~h}$ at $4{ }^{\circ} \mathrm{C}$. The crude extract samples were centrifuged at $9000 \times g$ for $20 \mathrm{~min}$ at $4{ }^{\circ} \mathrm{C}$. Solid $\left(\mathrm{NH}_{4}\right)_{2} \mathrm{SO}_{4}$ was added to the supernatant to obtain $80 \%$ saturation. After that, the precipitated proteins were separated by centrifugation at $9000 \times g$ for $30 \mathrm{~min}$ at $4{ }^{\circ} \mathrm{C}$. The precipitate was dissolved in $60 \mathrm{~mL}$ of 5-mM TRIS-HCl ( $\mathrm{pH} 7.0$ ) and was dialyzed for $48 \mathrm{~h}$ using the same buffer in a cellulose bag with a membrane MWCO bigger than $12,000 \mathrm{Da}$ at $4{ }^{\circ} \mathrm{C}$. Afterwards, the dialysate was transferred to a DEAE-Sepharose column $(20 \times 250 \mathrm{~mm})$ equilibrated with $5 \mathrm{mM}$ of TRIS-HCl buffer, $\mathrm{pH}$ 6.5. Proteins were eluted, employing a linear gradient of 0 to $1.0 \mathrm{M}$ of $\mathrm{NaCl}$ in $5 \mathrm{mM}$ of TRIS- $\mathrm{HCl}$ buffer (pH 6.5) at a $30-\mathrm{mL} \cdot \mathrm{h}^{-1}$ flow rate. Three-milliliter fractions were collected, for which protein content $(280 \mathrm{~nm})$ and PPO activity toward catechol as a substrate were monitored. Fractions that showed PPO activity were collected.

\subsection{Characterization of PPO}

\subsubsection{Kinetic Data Analysis and Substrate Specificity}

The specificity of PPOs from the lentil sprout extract was investigated for five commercial grade substrates (catechol, 4-methylcatechol, gallic acid, caffeic acid, and (+)-catechin) at concentrations of 1 , $5,10,20$, and $30 \mathrm{mM}$. The Michaelis constant $(\mathrm{Km})$, maximum reaction velocities $\left(V_{\max }\right)$, and specificity $\left(V_{\max } / \mathrm{Km}\right)$ of the PPOs were determined with the Lineweaver-Burk method.

\subsubsection{Effect of Temperature on Enzyme Activity}

PPO activity was determined as a function of temperature in standard conditions at a temperature range of $20-80^{\circ} \mathrm{C}$. The optimum temperature for the PPO was determined using $50 \mathrm{mM}$ of catechol as a substrate. The substrate solution was heated to the tested temperature, and then the enzyme solution was added. PPO activity was calculated in the form of percent residual PPO activity at the optimum temperature.

\subsubsection{Effect of $\mathrm{pH}$ on Enzyme Activity}

PPO activity was determined as a function of $\mathrm{pH}$ in standard conditions using various buffers in the $\mathrm{pH}$ buffering range of 3.5-8.0 (3.5-5.5 acetate buffer, $100 \mathrm{mM}$; 5.5-8.0 potassium phosphate buffer, $100 \mathrm{mM}$ ). The optimum $\mathrm{pH}$ for the PPO was determined using $0.05 \mathrm{M}$ of catechol as a substrate. The $\mathrm{pH}$ value corresponding to the highest enzyme activity was taken as the optimal $\mathrm{pH}$. PPO activity was calculated in the form of residual PPO activity at the optimum $\mathrm{pH}$.

\subsubsection{Effect of Antibrowning Agents on PPOs}

The effects of ascorbic acid, citric acid, EDTA, L-cysteine, sodium azide, dithiothreitol, and sodium metabisulfite on PPO activity were examined. Three different concentrations of these inhibitors $(0.2,2$, and $20 \mathrm{mM}$ ) were tested using $50 \mathrm{mM}$ of the catechol substrate and were compared to a control enzyme reaction performed in optimal conditions with no inhibitor added. Percentage inhibition was calculated using the following equation:

$$
\text { Inhibition }(\%)=\left(A_{0}-A_{i} / A_{0}\right) \times 100 \% \text {, }
$$

where $A_{0}$ is initial PPO activity (without the inhibitor), and $A_{i}$ is PPO activity with the inhibitor.

\subsubsection{Effect of Ions on Enzyme Activity}

The effect of ions, including $\mathrm{Na}^{+}, \mathrm{K}^{+}, \mathrm{Mg}^{2+}, \mathrm{Zn}^{2+}, \mathrm{Ba}^{2+}, \mathrm{Fe}^{3+}$, and $\mathrm{Mn}^{2+}$ (chloride salts), on PPO activity was determined. Two different concentrations of these cations ( 2 and $10 \mathrm{mM})$ were tested 
using $50 \mathrm{mM}$ of the catechol substrate. The effect of the studied ions on PPO activity was calculated in the form of percent residual PPO activity in comparison to the nontreated enzyme preparation.

\subsection{Statistical Analysis}

All data are presented as means including standard deviations (SDs) of three assays (means $\pm \mathrm{SD}$, $n=3)$.

\section{Results and Discussion}

\subsection{PPO Isolation and Partial Purification}

PPO was partially purified using a combination of ammonium sulfate precipitation and ion exchange chromatography (Figure 1). Two isoenzymes of PPO were found: PPO I and PPO II. The results of the purification of PPO are given in Table 1. After ammonium sulfate precipitation, the yield and purification fold were $90.6 \%$ and 4.67 , respectively. The purification folds after ion exchange chromatography were 26.1 and 25.11 for the first and second isoenzymes, respectively. Further biochemical studies were performed on the first and second isoenzymes (important data in the enzymology field) and the total (crude extract) PPOs (data for food technology).

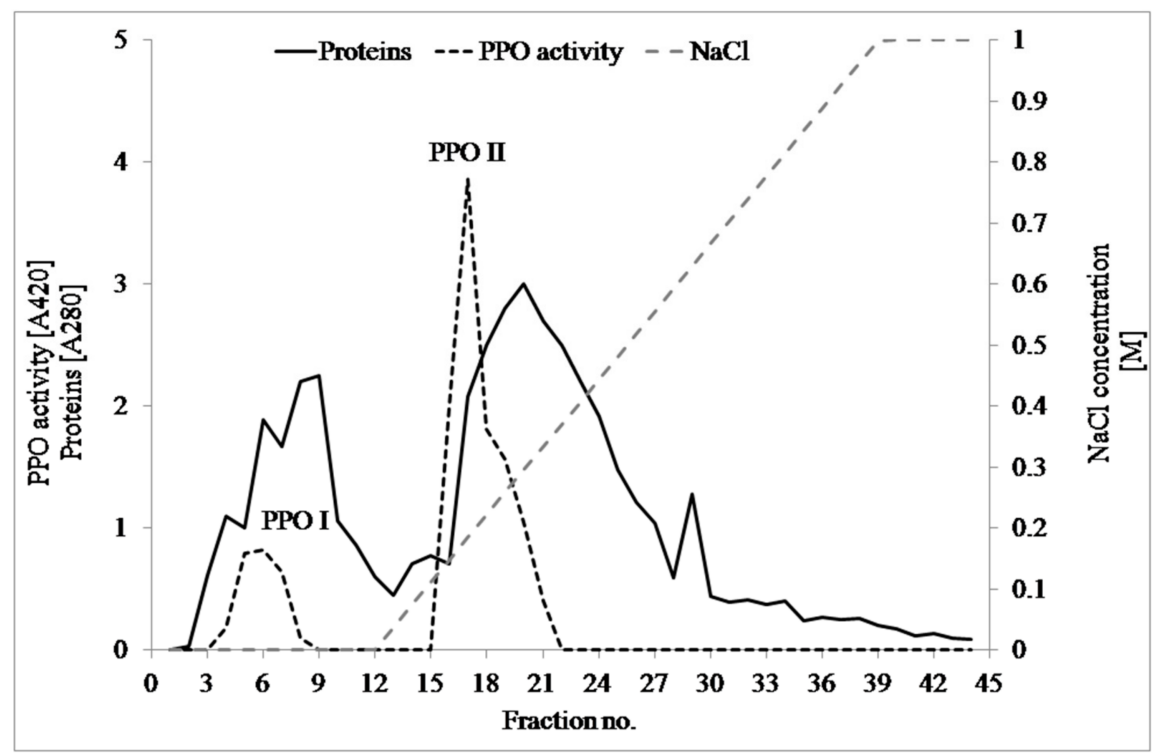

Figure 1. Anion exchange chromatographic elution profiles obtained after applying dissolved and desalted saline precipitate extract of lentil sprouts.

Table 1. Purification chart of polyphenol oxidases (PPOs) from lentil sprouts.

\begin{tabular}{cccccccc}
\hline & $\begin{array}{c}\text { Total Volume } \\
(\mathbf{m L})\end{array}$ & $\begin{array}{c}\text { Activity } \\
\mathbf{( U / m L )}\end{array}$ & $\begin{array}{c}\text { Protein } \\
\mathbf{( m g / m L )}\end{array}$ & $\begin{array}{c}\text { Total } \\
\text { Activity (U) }\end{array}$ & $\begin{array}{c}\text { Specific Activity } \\
\mathbf{( U / m g )}\end{array}$ & $\begin{array}{c}\text { Yield } \\
(\mathbf{\%})\end{array}$ & $\begin{array}{c}\text { Purification } \\
\text { Fold }\end{array}$ \\
\hline $\begin{array}{c}\text { Crude extract } \\
\text { Salting out and dialysis }\end{array}$ & 250 & 550 & 732.00 & 137500 & 0.75 & 100.0 \\
Ion exchange PPO I & 55 & 2265 & 644.97 & 124575 & 3.51 & 1.00 \\
chromatography & 13 & 1815 & 92.56 & 23595 & 19.61 & 17.16 \\
\hline
\end{tabular}

Catechol was used as a substrate for measuring PPO activity. An increase in absorbance of $0.001 \mathrm{~min}^{-1}$ was taken as one unit of enzyme activity.

\subsection{Substrate Specificity and Some Kinetic Parameters of Lentil Sprout PPOs}

PPO kinetics were studied with four substrates, those commonly used for PPO assays (catechol, 4-methylcatechol) as well as those that are important from the nutraceutical point of view (gallic and 
caffeic acids). The $K_{m}$ and $V_{\max }$ values calculated from the Lineweaver-Burk graphs are shown in Table 2. The values of $V_{\max }$ and catalytic efficiency $\left(V_{\max } / K_{m}\right)$ indicated that 4-methylcatechol was the most suitable phenolic substrate for lentil sprout PPOs (Table 2). The $V_{\max }$ values of total PPOs as well as PPO I and PPO II isoenzymes against gallic acid were also very high, but the $K_{m}$ of total PPOs was nearly twice and three times higher than the first and second isoenzymes. Most importantly, only PPO I used caffeic acid as a substrate $\left(K_{m}=3.8 \mathrm{mM}, V_{\max }=769 \mathrm{U} \cdot \mathrm{mL}^{-1} \cdot \mathrm{min}^{-1}\right)$. Total PPOs as well as PPO I and PPO II had the greatest affinity for catechol $\left(K_{m}=1.32,1.76\right.$, and $0.94 \mathrm{mM}$, respectively). These values were lower than those previously determined for persimmon $\left(K_{m}=25 \mathrm{mM}\right.$; sodium acetate buffer, pH 5.5) [15], green beans ( $K_{m}=10.6$ and $37 \mathrm{mM}$ for PPOI and PPOII, respectively; phosphate buffer, $\mathrm{pH}$ 7.0) [22], and mango fruit $\left(K_{m}=10.6 \mathrm{mM}\right.$, sodium acetate buffer, $\mathrm{pH}$ 5.6) [23]. All the studied PPOs of lentil sprouts exhibited the highest affinity for catechol: Hence, it was used as a substrate in further biochemical assays.

Table 2. Kinetic parameters of PPOs from lentil sprouts assessed with the use of several phenol substrates.

\begin{tabular}{|c|c|c|c|c|}
\hline & & $\begin{array}{c}V_{\max } \\
\left(\mathrm{U} \cdot \mathrm{mL}^{-\mathbf{1}} \cdot \min ^{-1}\right)\end{array}$ & $K m(\mathbf{m M})$ & $\begin{array}{c}V_{\max } / \mathrm{Km} \\
\left(\mathrm{U} \cdot \mathrm{mL}^{-1} \cdot \min ^{-1} \cdot \mathrm{mM}^{-1}\right)\end{array}$ \\
\hline \multirow{3}{*}{ 4-methylcatechol } & PPO I & $4878 \pm 244$ & $3.00 \pm 0.14$ & 1626 \\
\hline & PPO II & $3846 \pm 192$ & $3.40 \pm 0.15$ & 1131 \\
\hline & Total & $5410 \pm 270$ & $1.50 \pm 0.07$ & 3607 \\
\hline \multirow{3}{*}{ Catechol } & PPO I & $952 \pm 48$ & $1.76 \pm 0.08$ & 541 \\
\hline & PPO II & $1111 \pm 56$ & $0.94 \pm 0.04$ & 1176 \\
\hline & Total & $1737 \pm 87$ & $1.32 \pm 0.06$ & 1320 \\
\hline \multirow{3}{*}{ Gallic acid } & PPO I & $2817 \pm 141$ & $2.25 \pm 0.10$ & 1250 \\
\hline & PPO II & $3742 \pm 152$ & $5.00 \pm 0.23$ & 769 \\
\hline & Total & $8250 \pm 413$ & $7.25 \pm 0.33$ & 1138 \\
\hline \multirow{3}{*}{ Caffeic acid } & PPO I & $769 \pm 38$ & $3.81 \pm 0.17$ & 202 \\
\hline & PPO II & 0 & 0 & 0 \\
\hline & Total & 0 & 0 & 0 \\
\hline
\end{tabular}

All values represent the means of triplicate measurements.

\subsection{Effect of Temperature and $p H$ on PPO Activity}

Figure 2A shows the influence of temperature on PPO activities in the assay conditions (pH 5.5 and $50 \mathrm{mM}$ catechol as a substrate). PPO I, PPO II, and total PPOs reached maximum activity at $35^{\circ} \mathrm{C}$. The optimal temperatures for PPO activity are substrate-dependent and may differ for PPOs obtained from various sources [24]. It has been reported that when catechol is used as a substrate, the optimum temperature is $40^{\circ} \mathrm{C}$ for PPOs from Chinese cabbage [25], soybean sprouts [26], and parsley [24]; and $25-30^{\circ} \mathrm{C}$ for bananas [27]. Higher optimal temperatures were reported by Serradell et al. [28] and Navarro et al. [15] for PPOs isolated from strawberries $\left(50^{\circ} \mathrm{C}\right)$ and persimmons $\left(55^{\circ} \mathrm{C}\right)$. 

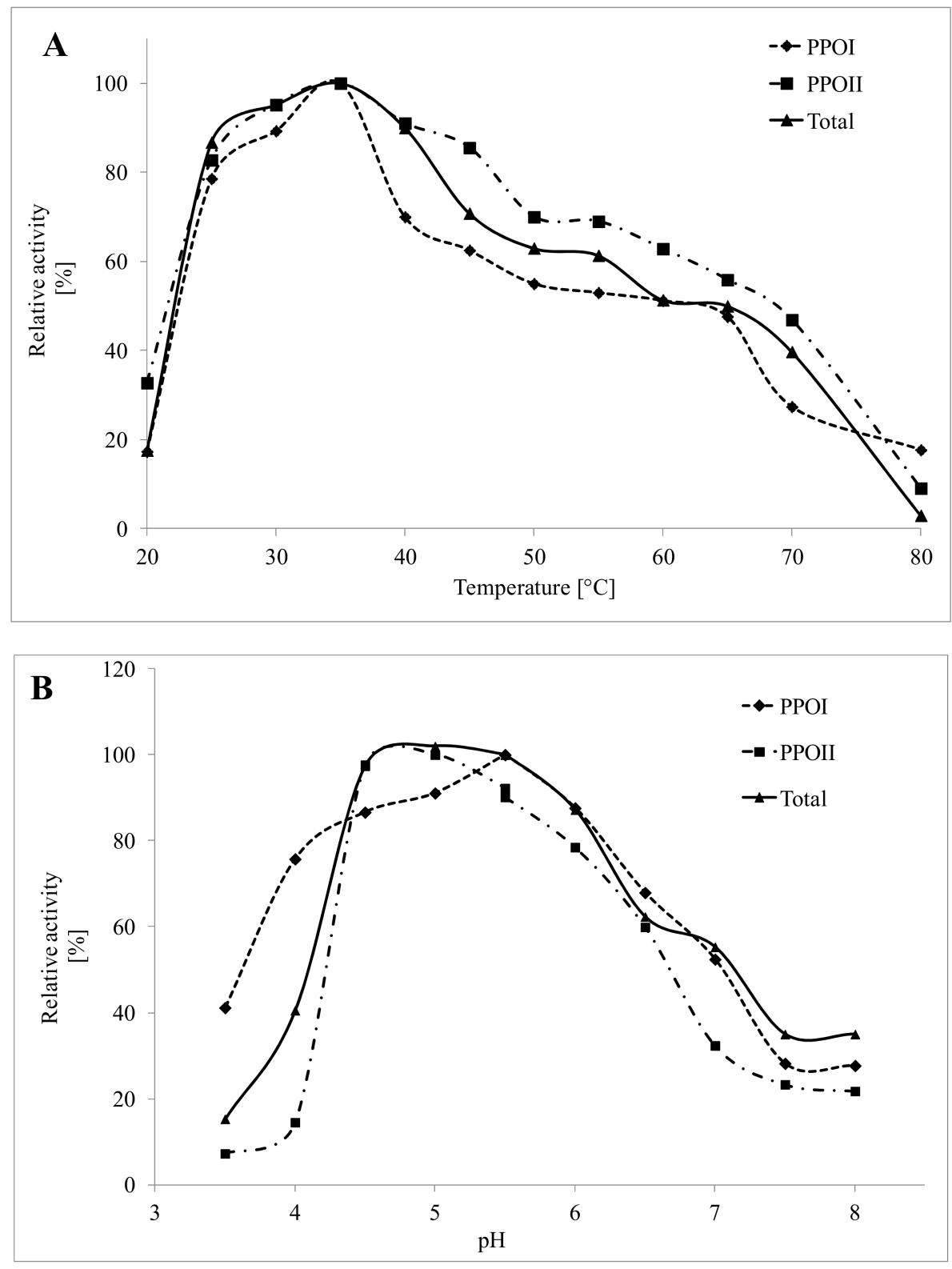

Figure 2. Effects of temperature (A) and $\mathrm{pH}(\mathbf{B})$ on the activity of lentil sprout PPOs.

The assay of PPO activity in a $\mathrm{pH}$ range from 4.0 to 8.0 , using catechol as a substrate, showed optimal conditions for total $\mathrm{PPO}$ activity in the $\mathrm{pH}$ range of 4.5-5.5. When the two PPO isoforms were studied separately, a pH of 4.5-5.0 and 5.5 were found to be optimal for PPO I and PPO II, respectively (Figure 2B). The pH optimum for PPO activity has been found to be dependent on the enzyme source and purity, substrate, and buffer system used [1]. In the available literature, different $\mathrm{pH}$ optima for PPO activity have been reported. Two $\mathrm{pH}$ optima, suggesting the presence of two PPO isoenzymes, have been previously reported by other researchers, i.e., 4.5-5.0 and 7.5-7.6, for two PPO isoenzymes from avocados [29]; 4.0 and 7.0 for green bean PPOs [22]; and 5.0 and 7.5 for Jonagored apple PPOs [30]. $\mathrm{A} \mathrm{pH}$ value of 5.5, i.e., the optimum $\mathrm{pH}$ for PPO activity determined in this study, agrees well with values that have been reported for lettuce [18] and mango fruit [23]. Contrarily, in a study performed by Nagai and Suzuki [26], PPOs from soybean sprouts exhibited optimal activity at pH 8-9. 


\subsection{Effect of Various Inhibitors and Metal Ions on PPO Activity}

The effects of antibrowning agents on the activity of PPOs from lentil sprouts were studied using catechol as a substrate. The results, i.e., the percentage of inhibition relative to the control, are reported in Table 3. Ascorbic acid was the most effective inhibitor of total PPOs and showed ca. $62 \%$, $43 \%$, and $24 \%$ of inhibition of dark pigment formation at $20-\mathrm{mM}, 2-\mathrm{mM}$, and $0.2-\mathrm{mM}$ concentrations, respectively. The production of dark quinones by both isoenzymes was most effectively inhibited by $20 \mathrm{mM}$ of ascorbic acid, L-cysteine, and sodium metabisulfite. These compounds also showed high efficiency at the lowest concentrations studied. Similar profiles have been previously found for PPOs from bananas [31], parsley [24], green beans [22], mango fruit [23], and soybean sprouts [26]. PPO II was also very sensitive to citric acid: Approximately $60 \%$ inhibition was recorded in the presence of $20 \mathrm{mM}$ of the inhibitor. Furthermore, the purified PPOs were much more sensitive to the studied inhibitors than the crude extract, probably because some components were able to mask the inhibitory effect of these compounds. The degree of dark pigment formation depends on the origin of the PPO and substrate used, and thus it is difficult to compare the present results to other studies. Yagar and Sagiroglu [32] recorded $98 \%$ and $100 \%$ of inhibition of quince PPOs in the presence of 2 and $20 \mathrm{mM}$ of ascorbic acid, respectively. For 2 and $20 \mathrm{mM}$ of sodium metabisulfite, the degree of inhibition was $52 \%$ and $98 \%$, respectively. As in other reports of the effect of antibrowning agents $[11,20,33,34]$, the activity of lentil sprout PPOs was also inhibited by a thiol-containing compound (dithiothreitol) and a copper-binding ligand (sodium azide, EDTA), but these compounds are very toxic and are banned as food additives. Thus, of the studied antibrowning agents, only ascorbic acid, citric acid, and L-cysteine are suitable to be used in food technology.

Table 3. Effects of various antibrowning agents on the activity of lentil sprout PPOs.

\begin{tabular}{ccccc}
\hline & $\begin{array}{c}\text { Concentration of Compounds } \\
(\mathbf{m M})\end{array}$ & \multicolumn{3}{c}{ \% of Inhibition } \\
\cline { 2 - 4 } & 20 & PPO I & PPO II & Total \\
\hline \multirow{3}{*}{ Ascorbic acid } & 2 & $79.66 \pm 3.03$ & $79.42 \pm 1.80$ & $62.57 \pm 2.38$ \\
& 0.2 & $50.85 \pm 1.93$ & $59.42 \pm 2.58$ & $43.86 \pm 1.67$ \\
& 20 & $46.61 \pm 1.77$ & $62.32 \pm 0.71$ & $24.56 \pm 0.93$ \\
\hline \multirow{2}{*}{-cysteine } & 2 & $71.67 \pm 2.72$ & $72.09 \pm 3.14$ & $26.97 \pm 1.02$ \\
& 0.2 & $68.33 \pm 2.60$ & $55.81 \pm 2.43$ & $21.35 \pm 0.81$ \\
& 20 & $56.67 \pm 2.15$ & $34.88 \pm 1.52$ & $10.11 \pm 0.38$ \\
\hline \multirow{2}{*}{$\mathrm{Na}_{2} \mathrm{~S}_{2} \mathrm{O}_{5}$} & 2 & $76.03 \pm 2.89$ & $71.58 \pm 3.11$ & $25.88 \pm 0.98$ \\
& 0.2 & $56.20 \pm 2.14$ & $64.21 \pm 2.79$ & $14.12 \pm 0.54$ \\
EDTA & 20 & $18.18 \pm 0.69$ & $24.21 \pm 1.05$ & $1.18 \pm 0.04$ \\
\hline \multirow{3}{*}{ Citric acid } & 2 & $26.67 \pm 1.01$ & $39.77 \pm 1.73$ & $14.63 \pm 0.56$ \\
& 0.2 & $24.17 \pm 0.92$ & $36.36 \pm 1.58$ & $3.66 \pm 0.14$ \\
& 20 & $20.83 \pm 0.79$ & $34.09 \pm 1.48$ & $2.44 \pm 0.09$ \\
\hline \multirow{3}{*}{ Sodium azide } & 2 & $30.13 \pm 1.14$ & $60.82 \pm 2.65$ & $43.18 \pm 1.64$ \\
& 0.2 & $22.44 \pm 0.85$ & $54.39 \pm 2.37$ & $37.88 \pm 1.44$ \\
\hline \multirow{2}{*}{ Dithiothreitol } & 20 & $7.69 \pm 0.29$ & $57.89 \pm 2.52$ & $8.33 \pm 0.32$ \\
\hline & 2 & $22.50 \pm 0.85$ & $22.89 \pm 1.00$ & $9.09 \pm 0.35$ \\
& 0.2 & $17.50 \pm 0.67$ & $15.66 \pm 0.68$ & $8.08 \pm 0.31$ \\
& 20 & $5.83 \pm 0.22$ & $8.43 \pm 0.37$ & $2.02 \pm 0.08$ \\
\hline
\end{tabular}

All values represent the means of triplicate measurements.

The effect of metal ions on the activity of PPOs is presented in Table $4 . \mathrm{Zn}^{2+}, \mathrm{Ba}^{2+}, \mathrm{Fe}^{3+}$, and $\mathrm{Mn}^{2+}$ at a 10-mM concentration completely inhibited the activity of PPOs. In contrast, in studies conducted by Liu et al. [35], both $\mathrm{Zn}^{2+}$ and $\mathrm{Mg}^{2+}(10 \mathrm{mM})$ increased the activity of PPOs from flower buds of Lonicera japonica by about $10 \%-15 \%$. In addition, Aydemir has reported [36] that the activity of 
PPOs from artichokes was only slightly inhibited by $\mathrm{Zn}^{2+}$ and $\mathrm{Mg}^{2+}$ at $1-$ and $10-\mathrm{mM}$ concentrations $\left(\mathrm{Fe}^{3+}\right.$ did not affect activity). Total PPOs, PPO I, and PPO II were inhibited by $2 \mathrm{mM}$ of $\mathrm{MgCl}_{2}: 50 \%$, $52 \%$, and $67 \%$ of residual activity was detected, respectively. According to literature data, the effect of $\mathrm{Mg}^{2+}$ on the activity of PPOs differs significantly and is strongly determined by the origin of the PPOs. The activity of PPOs from flower buds of Lonicera japonica has been activated by ions at 1-100 mM concentrations [35], whereas reduced activity has been noted at lower concentrations of ions (0.1-0.01 mM). An opposite relationship has been observed for PPOs from green beans [22] and artichokes [36]. There was no effect of $10 \mathrm{mM}$ of $\mathrm{K}^{+}$on the activity of PPOs (except PPO I): However, at the 2-mM concentration, these ions activated PPO I, PPO II, and total PPOs. A similar pattern of relationships was recorded for total PPOs, PPO I, and $\mathrm{Na}^{+}$ions. It has been previously reported that $\mathrm{Na}^{+}$ions either did not affect or only slightly modified the activity of PPOs, e.g., from green beans [22], flower buds of Lonicera japonica [35], or artichokes [36]. On the other hand, the activities of PPOs from Ataulfo mango and Anamur banana have been inhibited by $\mathrm{Na}^{+}$ions $[18,21]$.

Table 4. Effects of metal ions on the activity of PPOs from lentil sprouts.

\begin{tabular}{cccc}
\hline \multirow{2}{*}{ Ion Concentration (mM) } & \multicolumn{2}{c}{ Residual Activity (\%) } \\
\cline { 2 - 4 } & & $\mathbf{1 0}$ & $\mathbf{2}$ \\
\hline \multirow{3}{*}{$\mathrm{Na}^{+}$} & PPO I & $75.82 \pm 3.26$ & $82.42 \pm 3.54$ \\
& PPO II & $90.38 \pm 3.89$ & $142.31 \pm 6.12$ \\
& Total & $89.81 \pm 3.86$ & $106.48 \pm 4.58$ \\
\hline \multirow{2}{*}{$\mathrm{K}^{+}$} & PPO I & $76.99 \pm 3.31$ & $118.58 \pm 5.10$ \\
& PPO II & $101.35 \pm 4.36$ & $159.46 \pm 6.86$ \\
& Total & $99.23 \pm 4.27$ & $109.46 \pm 4.71$ \\
$\mathrm{Mg}^{2+}$ & PPO I & $46.90 \pm 2.02$ & $50.44 \pm 2.17$ \\
& PPO II & $51.35 \pm 2.21$ & $52.70 \pm 2.27$ \\
& Total & $61.54 \pm 2.65$ & $67.69 \pm 2.91$ \\
\hline \multirow{2}{*}{$\mathrm{Zn}^{2+}$} & PPO I & $\mathrm{Nd}$ & $42.24 \pm 1.82$ \\
& PPO II & $\mathrm{Nd}$ & $38.42 \pm 1.65$ \\
& Total & $\mathrm{Nd}$ & $48.78 \pm 2.10$ \\
$\mathrm{Ba}^{2+}$ & PPO I & $\mathrm{Nd}$ & $54.23 \pm 2.33$ \\
& PPO II & $\mathrm{Nd}$ & $54.43 \pm 2.34$ \\
& Total & $\mathrm{Nd}$ & $86.05 \pm 3.70$ \\
\hline \multirow{2}{*}{$\mathrm{Fe}^{3+}$} & PPO I & $\mathrm{Nd}$ & $53.49 \pm 2.30$ \\
& PPO II & $\mathrm{Nd}$ & $56.96 \pm 2.45$ \\
$\mathrm{Mn}^{2+}$ & Total & $\mathrm{Nd}$ & $58.28 \pm 2.51$ \\
\hline \multirow{2}{*}{} & PPO I & $\mathrm{Nd}$ & $48.98 \pm 2.11$ \\
& PPO II & $\mathrm{Nd}$ & $32.92 \pm 1.42$ \\
\hline \multirow{2}{*}{} & Total & $\mathrm{Nd}$ & $27.30 \pm 1.17$ \\
\hline
\end{tabular}

All values represent the means of triplicate measurements. $\mathrm{Nd}$ : not detected.

\section{Conclusions}

Lentil sprouts are widely consumed all over the world. Enzymatic browning of sprouts during storage is a serious problem negatively influencing their consumer quality. Identifying and understanding the mechanism of inhibition of polyphenol oxidases (PPOs) in lentil sprouts may offer inexpensive alternatives in preventing browning. Our findings indicated that supplementation of sprouts with metal ions $\left(\mathrm{Zn}^{2+}, \mathrm{Mn}^{2+}, \mathrm{Fe}^{3+}\right)$ and/or inhibitors (ascorbic acid, citric acid) may be used for decreasing the activity of PPOs. This strategy seems to be justified, but more research is needed to define effects on the growth and metabolism of sprouts, as well as their nutritional and pro-health qualities. 
Author Contributions: Conceptualization, M.S. and M.Ś.; methodology, M.S. and U.Z.; software, M.F.; validation, M.Ś., A.J., and M.F.; formal analysis, M.Ś.; investigation, M.S., A.J., M.F., J.B., and U.Z.; resources, M.Ś.; data curation, M.S.; writing—original draft preparation, M.S., J.B., and M.Ś.; writing—review and editing, M.S. and M.Ś.; visualization, M.S.; supervision, M.Ś.; project administration, M.S.; funding acquisition, M.Ś.

Acknowledgments: The authors would like to thank the Scientific Students Group of Food Biochemistry and Nutrition, Department of Biochemistry and Food Chemistry, University of Life Sciences in Lublin, Poland, for their technical support.

Conflicts of Interest: The authors declare no conflicts of interest.

\section{References}

1. Yoruk, R.; Marshall, M.R. Physicochemical properties and function of plant polyphenol oxidase: A review. J. Food Biochem. 2003, 27, 361-422. [CrossRef]

2. Mayer, A.M. Polyphenol oxidases in plants and fungi: Going places? A review. Phytochemistry 2006, 67, 2318-2331. [CrossRef]

3. Vaughn, K.C.; Duke, S.O. Function of polyphenol oxidase in higher plants. Physiol. Plant. 1984, 60, $106-112$. [CrossRef]

4. Chabanet, A.; Goldberg, R.; Catesson, A.M.; Quinet-Szely, M.; Delaunay, A.M.; Faye, L. Characterization and Localization of a Phenoloxidase in Mung Bean Hypocotyl Cell Walls. Plant Physiol. 1994, 106, 1095-1102. [CrossRef]

5. McDougall, G.J.; Stewart, D.; Morrison, I.M. Cell-wall-bound oxidases from tobacco (Nicotiana tabacum) xylem participate in lignin formation. Planta 1994, 194, 9-14. [CrossRef]

6. Zhang, Q.; Liu, Y.; He, C.; Zhu, S. Postharvest Exogenous Application of Abscisic Acid Reduces Internal Browning in Pineapple. J. Agric. Food Chem. 2015, 63, 5313-5320. [CrossRef]

7. Sun, Y.; Zhang, W.; Zeng, T.; Nie, Q.; Zhang, F.; Zhu, L. Hydrogen sulfide inhibits enzymatic browning of fresh-cut lotus root slices by regulating phenolic metabolism. Food Chem. 2015, 177, 376-381. [CrossRef]

8. Yi, J.H.; Dong, X.L.; Zhu, Z.B. Effect of polyphenol oxidase (PPO) enzymatic inducing factors on non-enzymatic browning of apple polyphenols. Mod. Food Sci. Technol. 2015, 31, 119-127.

9. Sikora, M.; Świeca, M. Effect of ascorbic acid postharvest treatment on enzymatic browning, phenolics and antioxidant capacity of stored mung bean sprouts. Food Chem. 2018, 239, 1160-1166. [CrossRef]

10. Sullivan, M.L. Beyond brown: Polyphenol oxidases as enzymes of plant specialized metabolism. Front. Plant Sci. 2014, 5, 783. [CrossRef] [PubMed]

11. Swieca, M.; Seczyk, L.; Gawlik-Dziki, U. Elicitation and precursor feeding as tools for the improvement of the phenolic content and antioxidant activity of lentil sprouts. Food Chem. 2014, 161, 288-295. [CrossRef]

12. Ali, H.M.; El-Gizawy, A.M.; El-Bassiouny, R.E.I.; Saleh, M.A. Browning inhibition mechanisms by cysteine, ascorbic acid and citric acid, and identifying PPO-catechol-cysteine reaction products. J. Food Sci. Technol. 2015, 52, 3651-3659. [CrossRef]

13. Arias, E.; González, J.; Peiró, J.M.; Oria, R.; Lopez-Buesa, P. Browning prevention by ascorbic acid and 4-hexylresorcinol: Different mechanisms of action on polyphenol oxidase in the presence and in the absence of substrates. J. Food Sci. 2007, 72, 464-470. [CrossRef]

14. Mishra, B.B.; Gautam, S.; Sharma, A. Purification and characterisation of polyphenol oxidase (PPO) from eggplant (Solanum melongena). Food Chem. 2012, 134, 1855-1861. [CrossRef]

15. Navarro, J.L.; Tárrega, A.; Sentandreu, M.A.; Sentandreu, E. Partial purification and characterization of polyphenol oxidase from persimmon. Food Chem. 2014, 157, 283-289. [CrossRef]

16. Gawlik-Dziki, U.; Szymanowska, U.; Baraniak, B. Characterization of polyphenol oxidase from broccoli (Brassica oleracea var. botrytis italica) florets. Food Chem. 2007, 105, 1047-1053. [CrossRef]

17. Aydemïr, T.; Akkanlı, G. Partial purification and characterisation of polyphenol oxidase from celery root (Apium graveolens L.) and the investigation of the effects on the enzyme activity of some inhibitors. Int. J. Food Sci. Technol. 2006, 41, 1090-1098. [CrossRef]

18. Gawlik-Dziki, U.; Złotek, U.; Świeca, M. Characterization of polyphenol oxidase from butter lettuce (Lactuca sativa var. capitata L.). Food Chem. 2008, 107, 129-135. [CrossRef] 
19. Świeca, M.; Gawlik-Dziki, U.; Kowalczyk, D.; Złotek, U. Impact of germination time and type of illumination on the antioxidant compounds and antioxidant capacity of Lens culinaris sprouts. Sci. Hortic. (Amsterdam). 2012, 140, 87-95. [CrossRef]

20. Cho, Y.K.; Ahn, H.K. Purification and characterization of polyphenol oxidase from potato: II. Inhibition and catalytic mechanism. J. Food Biochem. 1999, 23, 593-605. [CrossRef]

21. Bradford, M.M. A rapid and sensitive method for the quantitation of microgram quantities of protein utilizing the principle of protein-dye binding. Anal. Biochem. 1976, 72, 248-254. [CrossRef]

22. Guo, L.; Ma, Y.; Shi, J.; Xue, S. The purification and characterisation of polyphenol oxidase from green bean (Phaseolus vulgaris L.). Food Chem. 2009, 117, 143-151. [CrossRef]

23. Cheema, S.; Sommerhalter, M. Characterization of polyphenol oxidase activity in Ataulfo mango. Food Chem. 2015, 171, 382-387. [CrossRef]

24. Doğru, Y.Z.; Erat, M. Investigation of some kinetic properties of polyphenol oxidase from parsley (Petroselinum crispum, Apiaceae). Food Res. Int. 2012, 49, 411-415. [CrossRef]

25. Nagai, T.; Suzuki, N. Partial purification of polyphenol oxidase from Chinese cabbage Brassica rapa L. J. Agric. Food Chem. 2001, 49, 3922-3926. [CrossRef]

26. Nagai, T.; Suzuki, N. Polyphenol oxidase from bean sprouts (Glycine max L.). J. Food Sci. 2003, 68, 16-20. [CrossRef]

27. Ünal, M.Ü. Properties of polyphenol oxidase from Anamur banana (Musa cavendishii). Food Chem. 2007, 100, 909-913. [CrossRef]

28. Serradell, M.D.L.A.; Rozenfeld, P.A.; Martínez, G.A.; Civello, P.M.; Chaves, A.R.; Añón, M.C. Polyphenoloxidase activity from strawberry fruit (Fragaria x ananassa, Duch., cv Selva): Characterisation and partial purification. J. Sci. Food Agric. 2000, 80, 1421-1427. [CrossRef]

29. Gómez-López, V.M. Some biochemical properties of polyphenol oxidase from two varieties of avocado. Food Chem. 2002, 77, 163-169. [CrossRef]

30. Rocha, A.M.C.; Morais, A.M.M. Characterization of polyphenoloxidase (PPO) extracted from 'Jonagored' apple. Food Control 2001, 12, 85-90. [CrossRef]

31. Lee, M.-K. Inhibitory effect of banana polyphenol oxidase during ripening of banana by onion extract and Maillard reaction products. Food Chem. 2007, 102, 146-149. [CrossRef]

32. Yağar, H.; Sağiroğlu, A. Partially purification and characterization of polyphenol oxidase of quince. Turkish J. Chem. 2002, 26, 97-103.

33. Złotek, U.; Gawlik-Dziki, U. Selected biochemical properties of polyphenol oxidase in butter lettuce leaves (Lactuca sativa L. var. capitata) elicited with dl- $\beta$-amino- $n$-butyric acid. Food Chem. 2015, 168, 423-429. [CrossRef] [PubMed]

34. Gandía-Herrero, F.; García-Carmona, F.; Escribano, J. Purification and characterization of a latent polyphenol oxidase from beet root (Beta vulgaris L.). J. Agric. Food Chem. 2004, 52, 609-615. [CrossRef] [PubMed]

35. Liu, N.; Liu, W.; Wang, D.; Zhou, Y.; Lin, X.; Wang, X.; Li, S. Purification and partial characterization of polyphenol oxidase from the flower buds of Lonicera japonica Thunb. Food Chem. 2013, 138, 478-483. [CrossRef] [PubMed]

36. Aydemir, T. Partial purification and characterization of polyphenol oxidase from artichoke (Cynara scolymus L.) heads. Food Chem. 2004, 87, 59-67. [CrossRef]

(C) 2019 by the authors. Licensee MDPI, Basel, Switzerland. This article is an open access article distributed under the terms and conditions of the Creative Commons Attribution (CC BY) license (http://creativecommons.org/licenses/by/4.0/). 